\title{
The influence of the degradability of concentrate protein in the rumen and of the lysine content of the concentrate on growth and feed efficiency in early-weaned calves
}

\author{
W. A. G. Veen and H. A. Vahl \\ CLO-Institute for Animal Nutrition 'De Schothorst', Lelystad, Netherlands
}

Received 31 November 1983; accepted 3 April 1984

Key-words: early-weaned calves, feeding trial, slowly degradable protein, lysine requirement

\section{Summary}

In two feeding trials involving 96 rearing calves each and based on a $2 \times 3$ factorial design, a comparison was made between concentrates containing rapidly and slowly rumen-degradable protein on the one hand and between concentrates with three lysine levels, namely 6,7 and $8 \mathrm{~g} / \mathrm{kg}$ or 7,8 and $9 \mathrm{~g} / \mathrm{kg}$ on the other hand. In a third feeding trial involving 84 animals, two feeds containing rapidly and slowly degradable protein were compared. The calves were weaned at 6 weeks and remained in the trial an additional 5 to 6 weeks. Concentrates were fed ad libitum from the age of 21 days and in two trials after weaning the animals were fed according to a plan based on body weight. Hay or prewilted grass silage was fed ad libitum.

The difference in protein degradability between feeds with rapidly degradable protein and those with slowly degradable protein was $28 \%$ and $36 \%$ in the second and third trial respectively, as measured with the nylon bag technique.

Those experimental treatments involving concentrates with slowly degradable protein resulted in a higher daily weight gain. Only in the last trial differences were statistically significant. Feed efficiency was usually better as well.

An increase in the lysine content of the concentrate from 6 to $8 \mathrm{~g} / \mathrm{kg}$ or from 7 to 9 $\mathrm{g} / \mathrm{kg}$ resulted in a statistically significant linear rise in daily weight gain and a linear rise in feed efficiency.

The conclusion was that rearing calves require a lysine content of at least $8 \mathrm{~g}$ per $\mathrm{kg}$ concentrate to ensure rapid growth up to $100 \mathrm{~kg}$ body weight.

In two of the three trials the consumption of roughage $(1 \times$ pre-wilted grass silage, $1 \times$ hay) was positively affected by the presence in the concentrate of slowly degradable protein. The lysine content of the concentrate had no significant effect on roughage consumption. 


\section{Introduction}

Under the influence of volatile fatty acids, mainly originating from fermentation of concentrate, the mucous layer of the rumen wall develops and papillae are formed, which greatly increase the nutrient absorption surface. Roughage consumption results in an enlargement of the forestomachs and a thickening of the muscle layer. In order to hasten the above developments and thus enable the calf to be weaned earlier, the animal should be given concentrates from the age of 2-3 weeks together with fresh drinking water and good-quality roughage. If the milk protein in the ration is to be replaced by concentrate protein, then the latter must meet certain requirements.

According to Tamminga (1982) the young growing ruminant has a high need for protein relative to energy, a need which is often not met by the nutrients. There are three ways to increase the protein supply at the duodenal level, namely by increasing the protein content of the feed, by making use of the oesophageal groove reflex or by decreasing the rumen degradability of the feed protein.

In the past our institute has carried out various feeding trials in which special attention was devoted to the protein content of calf feeds. The results of these trials led to the establishment of a requirement of $15 \%$ digestible crude protein (dcp), equivalent to about $17.5 \%$ crude protein (cp). This is slightly more than Stobo et al. (1967) regarded as optimal, namely $15 \% \mathrm{cp}$.

The second way to increase the protein supply is to make use of the oesophageal groove reflex. Guilhermet et al. (1977) could considerably improve calf growth by feeding milk proteins in the form of casein and whey as liquid supplements, besides hay and a concentrate containing cereals and soya bean oil meal. These liquid supplements enter the abomasum directly by way of the oesophageal groove, so that glucose, galactose and amino acids can be absorbed by the intestine. Pryor \& Ternouth (1972) weaned calves at 25 days and then fed them either on a mixture of $90 \%$ dried skim milk powder and $10 \%$ chopped lucerne, or skim milk in liquid form and a limited quantity of lucerne, or liquid skim milk and lucerne ad libitum. The latter combination produced the best results. This was in accordance with the results of Stobo (1982) who even established that the rate of growth in the weight range from 80 to $100 \mathrm{~kg}$ was lower when milk protein was the only source of added protein than when whitefish meal, toasted soya bean oil meal or a mixture of these protein sources with skim milk powder was added. In our own trials the addition of $10-20 \%$ skim milk powder in the concentrate did not result in a significantly better growth rate in comparison with calves which did not receive milk protein in the concentrate (unpublished results). These findings clearly show that a calf can only benefit from milk proteins when they are given in liquid form. Milk protein that is added to the concentratie is quickly degraded in the rumen to ammonia and volatile fatty acids, so that the favourable amino acid pattern is of no value.

The significance of the degradability of protein in the rumen of calves for the nutritional value of the concentrate has already been studied by Whitelaw et al. (1961), Whitelaw \& Preston (1963) and Whitelaw et al. (1963). The results of trials with slowly degradable protein in dairy cattle feeds, carried oud at our institute and 
elsewhere, led us to apply the phenomenon of slowly degradable protein in our own feeding trials with calves, thus carrying the ideas of Whitelaw and his associates a step further.

When a sizeable portion of the feed protein passes through the rumen without being degraded, it is also possible to exert some influence on the amino acid pattern of the digesta. Whitelaw \& Preston (1963) found indications that the level of lysine in slowly degradable protein is significant; methionine did not prove to be a limiting amino acid when feeds were used which contained flaked maize with groundnut oil meal or fishmeal. Preston et al. (1964) found that the addition of lysine- $\mathrm{HCl}$ had no effect on a ration with a low lysine content, because the lysine was quickly degraded in the rumen.

The tissue protein of calves containes about $9.0 \mathrm{~g}$ lysine per $100 \mathrm{~g}$ protein, and cow's milk about $8.0 \mathrm{~g}$ (Oldham, 1980). We calculated the lysine content of a number of concentrates manufactured in the spring of 1979 and found this to be 3.8 $\mathrm{g} / 100 \mathrm{~g}$ of protein. Similar comparisons for the sulphur-containing amino acids led to the conclusion that the level in the concentrate was approximately the same as that of cow's milk and beef.

Rumen micro-organisms, on the other hand, contain a great deal of lysine and little methionine and cystine. Bacteria contain $7-9 \mathrm{~g}$ of lysine per $100 \mathrm{~g}$ of protein and protozoa $9-13 \mathrm{~g}$, while the methionine levels are 2 and $1.3-1.9 \mathrm{~g}$ respectively (Bergen et al., 1968; Oldham, 1980). The ration has no significant effect on these levels (Bergen et al., 1968). Thus the influence of the amino acid pattern of the ration protein is closely connected with the ratio of microbial protein to feed protein in the total quantity of protein reaching the small intestine.

In three trials we investigated whether weight gain in rearing calves can be improved by the addition of certain feedstuffs selected according to protein solubility, and whether under these circumstances lysine is limiting.

\section{Material and methods}

Two feeding trials (RF-A19 and RF-A20) were carried out with 96 calves each, according to a $2 \times 3$ factorial design and a third trial (RF-A21) with two treatments and 84 calves. The number of bull calves was 18,15 and 19 respectively. The calves were cross-breeds of Dutch Friesians and Holstein Friesians.

In trial A19 six concentrates were used containing easily and slowly fermentable protein respectively and with 6,7 and $8 \mathrm{~g}$ lysine per $\mathrm{kg}$. In trial A20 the lysine levels were 7,8 and $9 \mathrm{~g} / \mathrm{kg}$. Trial A21 involved two treatments, namely feeding with concentrates containing easily and slowly fermentable protein respectively. The lysine content of both concentrates was $8 \mathrm{~g} / \mathrm{kg}$. The composition of the concentrates is given in Table 1. In trials $\mathrm{A} 19$ and $\mathrm{A} 20$ feeds $\mathrm{C}$ and $\mathrm{D}$ were prepared by mixing equal parts of $\mathrm{A}$ and $\mathrm{E}$, and $\mathrm{B}$ and $\mathrm{F}$ respectively.

The calves were involved in the trial from 3 to 11 or 12 weeks of age. They were housed in crates with straw-bedded, wooden-slatted floors.

Table 2 gives the feeding plan. The milk replacer was fed once a day, in the morning, in a concentration of $125 \mathrm{~g}$ milk replacer per litre. One hour after the calves had 
Table 1. Composition of calf starters (\%).*

\begin{tabular}{|c|c|c|c|c|c|c|c|c|c|c|}
\hline \multirow{3}{*}{$\begin{array}{l}\text { lysine content, } \mathrm{g} / \mathrm{kg} \\
\text { Feedstuff }\end{array}$} & \multicolumn{4}{|c|}{ RF-A19 } & \multicolumn{4}{|c|}{ RF-A20 } & \multirow{2}{*}{\multicolumn{2}{|c|}{ RF-A21 }} \\
\hline & \multicolumn{2}{|l|}{6} & \multicolumn{2}{|l|}{8} & \multicolumn{2}{|l|}{7} & \multicolumn{2}{|l|}{9} & & \\
\hline & A & $\mathrm{B}$ & $E$ & $\mathrm{~F}$ & A & $\mathbf{B}$ & $\mathrm{E}$ & $\mathrm{F}$ & A & B \\
\hline maize & - & 15.0 & - & 31.3 & - & 10.0 & - & 15.0 & - & 30.0 \\
\hline barley & - & 29.25 & - & 30.0 & - & 25.0 & - & 24.0 & - & - \\
\hline wheat & 15.0 & - & 30.0 & - & 25.0 & - & 25.0 & - & 25.0 & - \\
\hline horsebeans & 2.6 & - & 19.0 & - & - & - & - & - & - & - \\
\hline peas & - & - & - & - & 3.0 & - & 18.0 & - & 5.0 & - \\
\hline lupin & - & - & - & - & - & - & - & - & 5.0 & - \\
\hline maize gluten meal & - & 2.0 & - & - & - & 5.0 & - & 2.0 & - & 5.0 \\
\hline maize gluten feed & 21.4 & - & 16.2 & - & 12.5 & - & 10.0 & - & 15.0 & - \\
\hline wheat middlings & - & - & - & - & - & - & - & - & 8.5 & - \\
\hline dried breweries grains & - & - & - & - & - & 5.0 & - & 5.0 & - & 10.0 \\
\hline dried citruspulp & 15.0 & - & 9.8 & - & - & - & - & - & - & - \\
\hline malt sprouts & - & - & - & - & 13.4 & - & - & -. & - & - \\
\hline soya beans & - & - & - & - & - & - & 2.0 & - & - & - \\
\hline soya beans, heat-treated & - & - & - & - & - & - & - & 3.5 & - & - \\
\hline linseed & 5.0 & - & 3.0 & - & 2.0 & - & - & - & - & - \\
\hline $\begin{array}{l}\text { linseed expeller } \\
\text { soya bean meal, solv. }\end{array}$ & 25.0 & - & - & - & 22.0 & - & 17.0 & - & - & - \\
\hline $\begin{array}{l}\text { extracted (cp } 48 \% \text { ) } \\
\text { soya bean meal, solv.- }\end{array}$ & - & - & - & - & - & 10.0 & 5.0 & 15.9 & 6.5 & 14.5 \\
\hline $\begin{array}{l}\text { soya bean meal, solv.- } \\
\text { extracted (cp } 44 \% \text { ) }\end{array}$ & - & 6.25 & 7.5 & 16.7 & - & - & - & - & - & - \\
\hline groundnut expeller & - & - & - & - & - & - & - & - & 10.0 & - \\
\hline coconut expeller & - & 30.0 & - & 9.0 & - & 20.0 & - & 7.5 & - & 15.0 \\
\hline lucerne meal & 5.0 & 10.0 & 5.0 & 5.0 & 7.0 & 7.0 & 7.0 & 7.0 & 7.0 & 7.0 \\
\hline tapioca meal & - & - & - & - & 7.2 & 9.9 & 8.0 & 12.0 & 9.3 & 10.0 \\
\hline $\begin{array}{l}\text { cane molasses } \\
\text { minerals/vitamins }\end{array}$ & 8.0 & 4.0 & 6.0 & 4.0 & 5.0 & 5.0 & 5.0 & 5.0 & 5.0 & 5.0 \\
\hline concentrate & 0.5 & 0.5 & 0.5 & 0.5 & 0.5 & 0.5 & 0.5 & 0.5 & 0.5 & 0.5 \\
\hline limestone & 0.7 & 0.7 & 1.0 & 1.1 & 0.6 & 0.2 & 0.5 & 0.2 & 0.7 & 0.5 \\
\hline calcium hydrogen phosphate & 1.0 & 1.5 & 1.2 & 1.6 & 1.0 & 1.6 & 1.2 & 1.6 & 1.2 & 1.7 \\
\hline sodium chloride & 0.8 & 0.8 & 0.8 & 0.8 & 0.8 & 0.8 & 0.8 & 0.8 & 0.8 & 0.8 \\
\hline soya bean oil & - & - & - & - & - & - & - & - & 0.5 & - \\
\hline $\begin{array}{l}\text { crude protein, } \mathrm{g} / \mathrm{kg} \\
\text { (determined) }\end{array}$ & 166 & 161 & 170 & 162 & 182 & 185 & 186 & 184 & 188 & 198 \\
\hline $\begin{array}{l}\text { lysine, } \mathrm{g} / \mathrm{kg} \text { (determined) } \\
\text { solubility of crude protein. }\end{array}$ & 5.9 & 5.6 & 7.7 & 7.7 & 7.2 & 6.6 & 8.5 & 8.6 & 8.0 & 8.1 \\
\hline$\%$ (determined) & 42 & 16 & 38 & 16 & 42 & 16 & 43 & 17 & 44 & 15 \\
\hline VEM & 960 & 947 & 950 & 946 & 943 & 942 & 947 & 937 & 943 & 946 \\
\hline
\end{tabular}

* Calf starters A and E contained easily degradable protein and B and F slowly degradable protein.

consumed the milk, pails of water were provided which remained available the rest of the day. Up to the age of 41 days approximately $23.5 \mathrm{~kg}$ of milk replacer powder was fed. During the second and third trials after weaning the concentrate was fed 
Table 2. Feeding plan (age in days).

\begin{tabular}{lllllll}
\hline & Colostrum & $\begin{array}{l}\text { Milk } \\
\text { replacer }\end{array}$ & $\begin{array}{l}\text { Calf } \\
\text { starter } \\
\text { ad libitum }\end{array}$ & $\begin{array}{l}\text { Calf } \\
\text { starter } \\
\text { according } \\
\text { to live- } \\
\text { weight }\end{array}$ & $\begin{array}{l}\text { Hay } \\
\text { ad libitum }\end{array}$ & $\begin{array}{l}\text { Pre-wilted } \\
\text { silage ad } \\
\text { libitum }\end{array}$ \\
RF-A19 & $0-6$ & $7-42$ & $21-77$ & - & $21-77$ & - \\
RF-A20 & $0-6$ & $7-42$ & $21-42$ & $43-84$ & - & $14-84$ \\
RF-A21 & $0-6$ & $7-42$ & $21-42$ & $43-84$ & $14-84$ & - \\
\hline
\end{tabular}

according to a feeding plan based on the formula $G^{0.75} \times 90, G$ being the body weight in $\mathrm{kg}$.

The quantity of milk replacer and concentrate consumed was determined on a daily basis and the amount of roughage twice a week. In the first trial the calves were weighed at birth and at the age of $3,6,9$ and 11 weeks. In the subsequent two trials they were weighed at birth and at the age of $3,6,8,10,11$ and 12 weeks. In trials A20 and A21 concentrate samples weighing $7 \mathrm{~g}$ and contained in small nylon bags were incubated in the rumen of 2-6 fistulated dairy cows that were fed at least 6 $\mathrm{kg}$ of concentrates per day, together with pre-wilted grass silage. At the end of 1,6 , 18 and 24 hours two bags at a time were removed from the rumen. The percentages of dry matter and crude protein present in the contents were determined. On the basis of the curve representing the relationship between the disappearance percentage of the crude protein and the incubation time, it was possible to calculate how much protein had disappeared after 12 hours. This value was used as standard in comparing the protein degradability in the rumen of the various rations. The soluble crude protein content of all the concentrates was determined according to Wohlt et al. (1973) with the modification by Crooker et al. (1978). In trial A20 a comparison was made between the lysine content of the feeds and that of the insoluble residues after one hour of incubation in a mineral buffer.

For the statistical evaluation of the results the weight of the calves at the age of 3 weeks was taken as covariable. The feed conversion was calculated as consumend $\mathrm{VEM}^{*}$ from concentrate and roughage per gram of growth.

\section{Results}

The protein solubility of the concentrates which were compared in these trials, at all lysine levels, varied from 15 to $17 \%$, and from 38 to $44 \%$ respectively. The protein solubility in mineral buffer is not always considered to be a good criterion for the fermentability of the protein (Mahadevan et al., 1980; Craig \& Broderick, 1981). For this reason in the second and third trials in sacco incubation of the feeds was carried out in the rumen of fistulated cows for several concentrates. The curves

\footnotetext{
* Dutch feed unit for dairy cows and calves.
} 


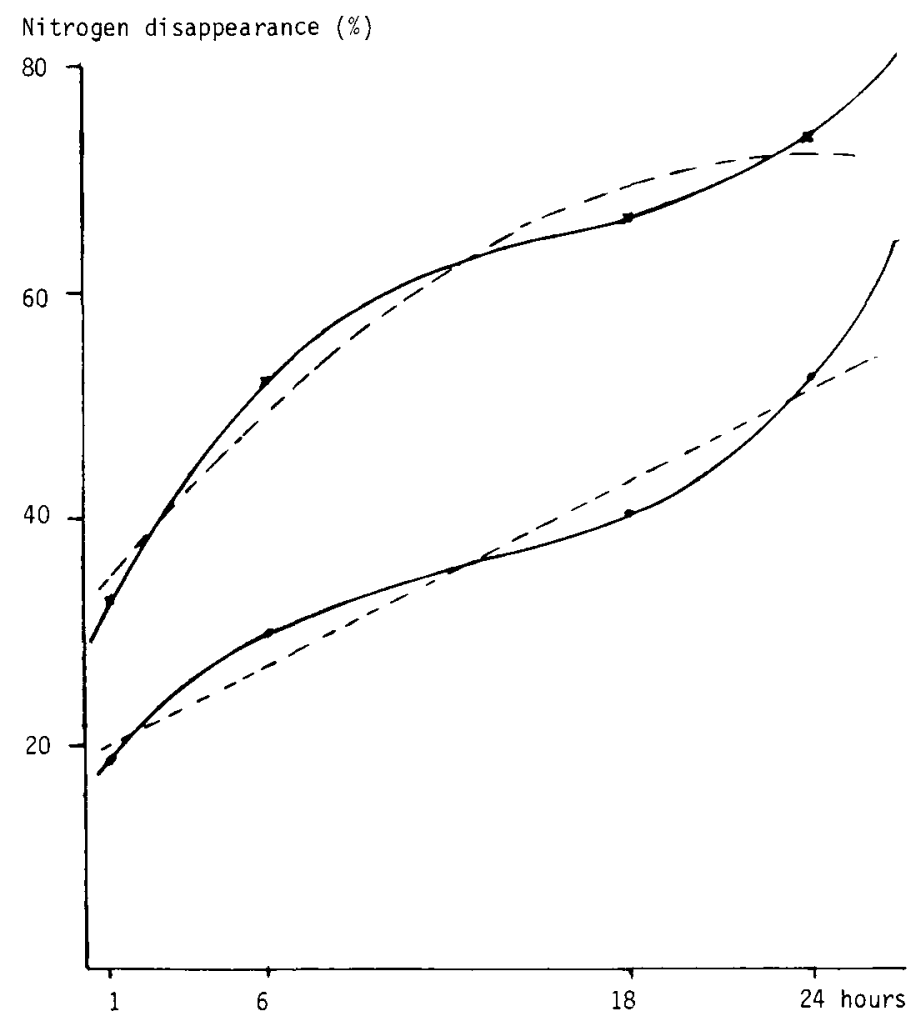

Fig. 1. Disappearance of nitrogen in calf feeds from nylon bags incubated in the rumen of fistulated cows.

- slowly degradable proteins; $x$ rapidly degradable protein.

— third-degree polynomial function; - - - second-degree polynomial function.

are described by second- and third-degree polynomial functions (Fig. 1).

In all the trials nearly all the milk replacer was consumed. At the time the calves were weaned (aged 6 weeks) they were consuming over $750 \mathrm{~g}$ of concentrate a day, in trials A20 and A21 as much as $1 \mathrm{~kg}$ on average. The average birth weight of the calves was $39.2,40.2$ and 42.3 respectively, the weight at the time of weaning was $59.7,63.6$ and $64.3 \mathrm{~kg}$. Thus the average gain up to weaning was $20.5,23.4$ and 22.0 $\mathrm{kg}$.

Tables 3, 4 and 5 show the weight gain and feed conversion for the various treatments with respect to the degradability of the ration protein. In all three trials there was a higher weight gain per day when the concentrate protein was slowly degradable in the rumen. In trials A20 and A21 this was even observed during the period that the calves were receiving milk replacer in addition to concentrate (21-42 days). It was only in trial A21 that the difference in weight gain between the two experimental treatments was statistically significant. The differences were smallest in trial A20. In trial A19 at all three lysine levels a higher concentrate consumption per day was observed on the rations with slowly degradable protein than on those with rap- 
Table 3. Live-weight gain and feed conversion as related to the degradability of concentrate protein in the rumen (Trial RF-A19)

\begin{tabular}{|c|c|c|c|c|}
\hline \multirow{2}{*}{$\begin{array}{l}\text { Age } \\
\text { (days) }\end{array}$} & & \multicolumn{2}{|c|}{ Concentrate protein } & \multirow{2}{*}{$\begin{array}{l}\text { Statistical } \\
\text { significance }\end{array}$} \\
\hline & & $\begin{array}{l}\text { easily } \\
\text { degradable }\end{array}$ & $\begin{array}{l}\text { slowly } \\
\text { degradable }\end{array}$ & \\
\hline $21-42$ & g/day & 497 & 492 & n.s. \\
\hline $43-77$ & $\begin{array}{l}\text { g/day } \\
\text { VEM/g weight gain }\end{array}$ & $\begin{array}{l}722 \\
2.64\end{array}$ & $\begin{array}{l}770 \\
2.53\end{array}$ & $\begin{array}{l}\text { n.s. } \\
P<0.05\end{array}$ \\
\hline $21-77$ & $\mathrm{~g} /$ day & 638 & 666 & n.s. \\
\hline
\end{tabular}

Table 4. Live-weight gain and feed conversion as related to the degradability of concentrate protein in the rumen (Trial RF-A20).

\begin{tabular}{|c|c|c|c|c|}
\hline \multirow{2}{*}{$\begin{array}{l}\text { Age } \\
\text { (days) }\end{array}$} & & \multicolumn{2}{|c|}{ Concentrate protein } & \multirow{2}{*}{$\begin{array}{l}\text { Statistical } \\
\text { significance }\end{array}$} \\
\hline & & $\begin{array}{l}\text { easily } \\
\text { degradable }\end{array}$ & $\begin{array}{l}\text { slowly } \\
\text { degradable }\end{array}$ & \\
\hline $21-42$ & $\mathrm{~g} /$ day & 519 & 541 & n.s. \\
\hline \multirow[t]{2}{*}{$43-84$} & $\mathrm{~g} /$ day & 895 & 903 & n.s. \\
\hline & $\mathrm{VEM} / \mathrm{g}$ weight gain & 2.51 & 2.53 & n.s. \\
\hline $21-84$ & $\mathrm{~g} /$ day & 759 & 782 & n.s. \\
\hline
\end{tabular}

Table 5. Live-weight gain and feed conversion as related to the degradability of concentrate protein in the rumen (Trial RF-A21).

\begin{tabular}{|c|c|c|c|c|}
\hline \multirow{2}{*}{$\begin{array}{l}\text { Age } \\
\text { (days) }\end{array}$} & & \multicolumn{2}{|c|}{ Concentrate protein } & \multirow{2}{*}{$\begin{array}{l}\text { Statistical } \\
\text { significance }\end{array}$} \\
\hline & & $\begin{array}{l}\text { easily } \\
\text { degradable }\end{array}$ & $\begin{array}{l}\text { slowly } \\
\text { degradable }\end{array}$ & \\
\hline $21-42$ & g/day & 501 & 529 & n.s. \\
\hline \multirow[t]{2}{*}{$43-84$} & g/day & 837 & 905 & $\mathrm{P}<0.01$ \\
\hline & $\mathrm{VEM} / \mathrm{g}$ weight gain & 2.69 & 2.53 & $\mathrm{P}<0.01$ \\
\hline $21-84$ & $\mathrm{~g} /$ day & 725 & 780 & $P<0.01$ \\
\hline
\end{tabular}

idly degradable protein ( $1355 \mathrm{~g} /$ day vs. $1298 \mathrm{~g} /$ day). The greatest difference was that between groups $\mathrm{F}$ and $\mathrm{E}$, which received feeds with $60 \%$ maize and barley and $30 \%$ wheat respectively. Thus a difference between the palatability of the various feeds may have had something to do with the improved feed consumption and weight gain. For this reason, in the next two trials the concentrate was fed according to a plan based on body weight. In trial A20, during the period up to weaning a slightly higher level of concentrate consumption was registered for the ration with slowly degradable protein $(18 \mathrm{~g})$, while during the period following weaning just the reverse was the case. In trial A21, during both periods the consumption of dry matter from the concentrate was higher for a ration with slowly degradable protein (30$31 \mathrm{~g} /$ day). As the calves were fed according to body weight, this must have been due 
Table 6. Live-weight gain and feed conversion as related to the lysine content of the calf starter (Trial RF-A19).

\begin{tabular}{|c|c|c|c|c|c|}
\hline \multirow{2}{*}{$\begin{array}{l}\text { Age } \\
\text { (days) }\end{array}$} & & \multicolumn{3}{|c|}{ Lysine content of concentrate } & \multirow{2}{*}{$\begin{array}{l}\text { Statistical } \\
\text { significance }\end{array}$} \\
\hline & & $6 \mathrm{~g} / \mathrm{kg}$ & $7 \mathrm{~g} / \mathrm{kg}$ & $8 \mathrm{~g} / \mathrm{kg}$ & \\
\hline $21-42$ & g/day & 490 & 477 & 516 & n.s. \\
\hline \multirow[t]{2}{*}{$43-77$} & g/day & 710 & 738 & 790 & lin. $(P<0.01)$ \\
\hline & VEM/g weight gain & 2.67 & 2.58 & 2.49 & lin. $(P<0.01)$ \\
\hline $21-77$ & g/day & 628 & 640 & 687 & lin. $(P<0.05)$ \\
\hline
\end{tabular}

Table 7. Live-weight gain and feed conversion as related to the lysine content of the calf starter (Trial RF-A20).

\begin{tabular}{|c|c|c|c|c|c|}
\hline \multirow{2}{*}{$\begin{array}{l}\text { Age } \\
\text { (days) }\end{array}$} & & \multicolumn{3}{|c|}{ Lysine content of concentrate } & \multirow{2}{*}{$\begin{array}{l}\text { Statistical } \\
\text { significance }\end{array}$} \\
\hline & & $7 \mathrm{~g} / \mathrm{kg}$ & $8 \mathrm{~g} / \mathrm{kg}$ & $9 \mathrm{~g} / \mathrm{kg}$ & \\
\hline $21-42$ & $\mathrm{~g} /$ day & 506 & 539 & 546 & n.s. \\
\hline $43-84$ & $\mathrm{~g} /$ day & 858 & 911 & 929 & lin. $(P<0.01)$ \\
\hline & VEM/g weight gain & 2.59 & 2.50 & 2.48 & n.s. \\
\hline $21-84$ & $\mathrm{~g} /$ day & 740 & 787 & 801 & lin. $(P<0.05)$ \\
\hline
\end{tabular}

to the improved weight gain registered by calves receiving slowly degradable protein.

In the first trial the consumption of roughage was poor. However, the hay then being fed was not of the best quality. In the second and third trials the consumption of dry matter from roughage was much higher, while consumption was affected by the nature of the protein in the concentrate. In trial A20, in the period after weaning $70 \mathrm{~g}$ per day more dry matter from prewilted grass silage was consumed on the treatment with slowly degradable concentrate protein than on one with rapidly degradable protein. This difference was statistically significant. In trial A21 dry matter consumption from hay was $42 \mathrm{~g}$ per day higher.

In trials A19 and A21 VEM conversion during the period after weaning was better for the treatment with slowly degradable protein; the difference was statistically significant.

The effect of the lysine level on growth and VEM conversion is given in Tables 6 and 7. After weaning higher lysine levels produced a significant linear increase in weight gain. In trial A19 the improvement in average daily weight gain produced by an increase in the lysine content was more pronounced on a feed containing slowly degradable protein than on one with rapidly degradable protein, although this interaction was not significant. Trial A 19 was the only one in which VEM conversion was affected to a statistically significant degree, but in A20 the VEM efficiency was also improved by a higher lysine content in the concentrate. In both trials concentrate consumption increased as the level of lysine rose. This might be expected in the case of trial A20, since the animals which grew fastest received the most concen- 
trate. The consumption of dry matter from roughage was not significantly affected by the lysine level.

In the period after weaning the effect of the lysine content on weight gain was most marked when the level of lysine was raised from 7 to $8 \mathrm{~g} / \mathrm{kg}$ concentrate.

\section{Discussion}

The slope of the nitrogen degradability curves (Fig. 1) was described by the functions $y=\mathrm{B}_{0}+\mathrm{B}_{1} \cdot x+\mathrm{B}_{2} \cdot x^{2}+\mathrm{B}_{3} \cdot x^{3}$ and $y=\mathrm{B}_{0}+\mathrm{B}_{1} \cdot x+\mathrm{B}_{2} \cdot x^{2}$ respectively. According to Ørskov \& McDonald (1979) such degradability curves can be described by means of an exponential function, but we often found such a function inadequate. The curves for the concentrates with highly soluble and poorly soluble protein had about the same shape but differed as far as the level was concerned.

If protein degradability after 12 houts of incubation is taken as the standard, the difference in the protein degradability percentage of the concentrates in trial A20 was $28 \%$ and in trial A21 $35 \%$. It made no difference whether the curve was described with a second- or third-degree polynomial. The differences in protein solubility in vitro varied from 22 to $29 \%$ (Table 1) and thus gave an excellent indication of differences in protein degradability.

The degree of protein degradability of the feed protein does not become a factor until the rumen function is sufficiently developed. Thus it is not surprising that during the period up to weaning (at the age of 21-42 days) the variations in concentrate protein did not have any clear effect. In the subsequent 5 or 6 weeks the effect was clearly observable. In trial A19 the difference was $48 \mathrm{~g}$ per animal per day, or $6.5 \%$ of average weight gain. Due to the large spread, this difference was not significant. Because the calves receiving slowly degradable protein consumed more concentrate of their own free will, the palatability of the feeds may have been a factor. However, the significantly better VEM conversion shows that the calves grew faster not only because of the increased intake of concentrates, but also through better feed efficiency. The consumption of roughage was negligible in this trial.

It is noteworthy that the roughage consumption in trials A20 and A21 is clearly higher on rations with slowly degradable protein. In dairy cows a connection has been shown between the protein level and the degree of protein degradability on the one hand, and the consumption of dry matter on the other hand. A generous supply of amino acids on the level of the intestine may promote the consumption capacity of lactating cows (Journet \& Rémond, 1981).

In trials A20 and A21, after weaning the concentrate was administered according to a plan based on body weight. Thus the possible effect of differences in palatability on feed consumption, and thus on weight gain is not a factor here. Trial A20 might lead one to conclude that the effect of protein degradability on growth and VEM conversion is of little consequence. In trial A21, however, large and statistically significant differences were found. The difference in in-vivo protein degradability between the two types of concentrate was, however, greater in this trial than in the previous one, as we have seen above. Whitelaw et al. (1961) discovered greater differences in the average daily growth of calves weighing about $70 \mathrm{~kg}$ when 
the in-vitro solubility of the concentrate protein was $48 \%$ and $18 \%$, thus comparable to the values for the concentrates we used in trial A21. Weight gain was, however, much lower than in our trials and the trial was carried out with only 6 calves, according to an experimental design based on $3 \times 3$ Latin square. Later a trial was carried out with 64 calves that remained under observation from 55 to $90 \mathrm{~kg}$ body weight. The animals were fed a ration containing $56 \%$ of the total nitrogen from whitefish meal (protein solubility $7 \%$ ), which produced a much better weight gain and better feed efficiency than a ration with groundnut oil meal (protein solubility $78 \%$; Whitelaw et al., 1963). Cummins et al. (1982) found no effect on growth or feed efficiency in somewhat older calves ( 8 -20 weeks) as a result of differences in the degradable protein in the rumen. However, a balance trial showed that nitrogen retention and utilization were highest on the ration containing the lowest percentage of rumen degradable protein.

It can be concluded from our trials that the growth of young calves can be improved if a higher than average portion of the ration protein is not degraded in the rumen. According to trials carried out by Veira et al. (1980a) with calves weighing ca. $150 \mathrm{~kg}$, a level of more than $12 \%$ crude protein leads to a loss of protein in the rumen. On the other hand, the young ruminating calf is shown to have a requirement for protein exceeding that which is provided by the rumen micro-organisms. When the protein requirement is supplied by slowly degradable protein weight gain and nitrogen retention increase and feed efficiency improves (Veira et al., 1980b).

The second factor tested in our trials was the lysine content of the concentrates. In trials A19 and A20 we noted a statistically significant positive effect on weight gain when the lysine level rose by $1 \mathrm{~g}$ per $\mathrm{kg}$ from $6-8$ or from $7-9 \mathrm{~g}$. The VEM conversion was also positively affected, but in trial A20 this was not statistically significant. In addition, it was interesting to note that the positive effect was already clearly observable during the period that the calves were being fed milk replacers plus concentrates. Boucqué et al. (1981) noted significantly better energy efficiency on concentrates with 14.8 or $16.2 \% \mathrm{cp}$, as compared to concentrates with 11.6 or $13.0 \% \mathrm{cp}$. According to calculation the former rations contained 6.9 and $8.9 \mathrm{~g} \mathrm{ly}$ sine per $\mathrm{kg}$ respectively, and the latter 4.4 and $5.6 \mathrm{~g}$.

Although one is not necessarily striving for maximum weight gain in rearing calves, we believe that the level of lysine in the concentrate in the growth range up to $100 \mathrm{~kg}$ ought to be at least $8 \mathrm{~g} / \mathrm{kg}$. From a survey of the literature then available Hatfield (1970) came to the conclusion that the amino acid pattern and the levels of the essential amino acids at the site of absorption in the intestine may be limiting factors for the synthesis of tissue protein in growing ruminants.

Devlin \& Woods (1965) noted a higher nitrogen retention in bulls that received, in addition to a control ration, a daily $9 \mathrm{~g}$ of lysine directly in the abomasum. However, in ruminants it is difficult to influence the amino acid composition of the digesta. The difficulties are greater the more rapidly the feed protein is fermented in the rumen. When a considerable portion of the feed protein is not degradable, the amino acid pattern of the undegradable portion of the protein, alongside that of the microbial protein, is determinative for the amino acid supply on the intestinal level. 
Table 8 . Lysine content in concentrates and residues of concentrates after $1 \mathrm{~h}$ incubation in mineral buffer (g/100 g protein) (Trial RF-A20).

\begin{tabular}{lll}
\hline & Concentrate & Residue \\
A & 3.9 & 4.0 \\
B & 3.6 & 3.5 \\
E & 4.5 & 4.2 \\
F & 4.8 & 4.4 \\
\hline
\end{tabular}

Examination of the protein residue of the concentrate after one hour's incubation in a mineral buffer showed nearly as much lysine as in the original feeds (Table 8). Data compiled by MacGregor et al. (1981) on 19 feedstuffs show that the amino acid pattern of the soluble protein generally deviates sharply from that of the total protein, the soluble protein often containing more lysine. Ganev et al. (1979), however, found that after an incubation in vivo of 9 hours in the rumen, the residues of a number of other feedstuffs differed only slightly in amino composition from the total protein. For two of the products the lysine content in the residue was higher than in the original protein. Thus it is not suprising that no great differences were observed in the case of concentrates which, as was the case in our trials, are composed of a great many different ingredients.

Although the protein that proves insoluble after one hour's incubation in a mineral buffer solution is certainly not completely undegradable after 12 to 24 hours in the rumen, we may safely assume that the differences in lysine levels in the concentrate protein are also largely reflected in the protein which reaches the small intestine. On the basis of these findings one might expect the effect of the lysine content to be greater in the case of a ration with slowly degradable protein. This tendency was however only observed in trial RF-A19 and was not statistically significant.

Thus for weight gain in calves lysine appears to be a limiting amino acid, a conclusion which is in agreement with the results of Whitelaw \& Preston (1963).

\section{References}

Bergen, W. G.. D. B. Purser \& J. H. Cline. 1968. Effect of ration on the nutritive quality of rumen microbial protein. Journal of Animal Science 27: 1497-1501.

Boucqué, Ch. V., L. O. Fiems, B. G. Cottyn \& F. X. Buysse, 1981. Het optimaal eiwitgehalte in krachtvoeders voor vroeg gespeende fokkalveren. 1. Invloed op de prestaties tijdens de opfokperiode. Landbouwtijdschrift 34: 1521-1537.

Craig, W. M. \& G. A. Broderick, 1981. Comparison of nitrogen solubility in three solvents to in vitro protein degradation of heat-treated cottonseed meal. Journal of Dairy Science 64: 769-774.

Crooker, B. A., C. J. Sniffen, W. H. Hoover \& L. L. Johnson, 1978. Solvents for soluble nitrogen measurements in feedstuffs. Journal of Dairy Science 61: 437-447.

Cummins, K. A., J. E. Nocek \& C. E. Polan, 1982. Growth and nitrogen balance of calves fed rations of varying nitrogen degradability and physical form. Journal of Dairy Science 65: 773-783.

Devlin, T. J. \& W. Woods, 1965. Nitrogen metabolism as influenced by lysine administration posterior to the rumen. Journal of Animal Science 24: 878-879.

Ganev, G., E. R. Orskov \& R. Smart, 1979. The effect of roughage or concentrate feeding and rumen 


\section{W. A. G. VEEN AND H. A. VAHL}

retention time on total degradation of protein in the rumen. Journal of Agricultural Science, Cambridge 93: 651-656.

Guilhermet, R., P. Patureau-Mirand, R. Toullec \& J. L. Paruelle, 1977. Utilisation de la gouttière oesophagienne pour éviter la dégradation dans le rumen, de mélanges de lactose et de caséine, chez le veau ruminant. Annales de Biologie Animale, Biochimie, Biophysique 17: 543-547.

Hatfield, E. E., 1970. Selected topics related to the amino acid nutrition of the growing ruminant. Federation Proceedings, Federation of American Societies for Experimental Biology 29: 44-50.

Journet. M. \& B. Rémond, 1981. Response of dairy cows to protein level in early lactation. Livestock Production Science 8: 21-35.

MacGregor, C. A., C. J. Sniffen \& W. H. Hoover, 1978. Amino acid profiles of total and soluble protein in feedstuffs commonly fed to ruminants. Journal of Dairy Science 61: 566-573.

Mahadevan, S., J. D. Erfle \& F. D. Sauer, 1980. Degradation of soluble and insoluble proteins by Bacteroides amylophilus protease and by rumen microorganisms. Journal of Animal Science 50: 723-728.

Oldham, J. D., 1980. Amino acid requirements for lactation in high-yielding dairy cows. In: Recent Advances in Animal Nutrition, Butterworths, London, p. 33-65.

Ørskov, E. R., \& I. McDonald, 1979. The estimation of protein degradability in the rumen from incubation measurements weighted according to rate of passage. Journal of Agricultural Science, Cambridge 92: 499-503.

Preston, T. R., F. G. Whitelaw \& N. A. MacLeod, 1964. The nutrition of the early weaned calf. VI. The effect of supplemental lysine and methionine on the utilisation of groudnut protein. Animal Production 6: 17-24.

Pryor, W. J. \& J. H. Ternouth, 1972. A comparison of feeding reconstituted and dried milk upon the growth and carcass composition of calves. British Journal of Nutrition 27: 517-525.

Stobo, I. J. F., J. H. B. Roy \& H. J. Gaston, 1967. The protein requirement of the ruminant calf. II. Further studies on the effect of protein content of the concentrate mixture on the performance of calves weaned at an early age. Animal Production 9: 23-33.

Stobo, I. J. F., J. H. B. Roy, P. Ganderton \& M. W. Perfitt, 1982. Protein requirements of the ruminant calf. National Institute for Research in Dairying, Report 1982, p. 59-60.

Tamminga, S. In: E. L. Miller, I. H. Pike, A. J. H. van Es (Eds.), Protein contribution of feedstuffs for ruminants: Application to feed formulation. Butterworths, London, 1982, pp. 4-17.

Veira, D. M., G. K. MacLeod, J. H. Burton \& J. B. Stone, 1980a. Nutrition of the weaned Holstein calf. I. Effect of dietary protein level on rumen metabolism. Journal of Animal Science 50: 937-944.

Veira, D. M., G. K. MacLeod, J. H. Burton \& J. B. Stone, 1980b. Nutrition of the weaned Holstein calf. II. Effect of dietary protein level on nitrogen balance, digestibility and feed intake. Journal of Animal Science 50: 945-951.

Whitelaw, F. G., T. R. Preston \& G. S. Dawson, 1961. The nutrition of the early weaned calf. II. A comparison of commercial groundnut meal, heat-treated groundnut meal and fish meal as the major protein source in the diet. Animal Production 3: 127-133.

Whitelaw, F. G. \&T. R. Preston, 1963. The nutrition of the early weaned calf. III. Protein solubility and amino acid composition as factors affecting protein utilisation. Animal Production 5: 131-145.

Whitelaw, F. G., T. R. Preston, N. A. MacLeod, 1963. The nutrition of the early weaned calf. V. The effect of protein quality, antibiotics and level of feeding on growth and feed conversion. Animal Production 5: 227-235.

Wohlt, J. E., C. J. Sniffen \& W. H. Hoover, 1973. Measurement of protein solubility in common feedstuffs. Journal of Dairy Science 56: 1052-1057. 